\title{
Graditi državu blagostanja
}

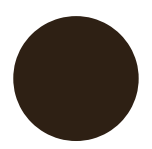

Dirk van den Heuvel, Jaap Bakema and the Open Society, Amsterdam: Archis, 2018. ISBN 9789077966570

DOI: 10.31664/zu.2018.102.08

Na poziv selektora Rema Koolhasa unutar problemske cjeline „Absorbing Modernity: 1914.-2014." 14. Venecijanskog bijenala arhitekture naslovljenog Fundamentals, Nizozemska je kao ključni trenutak modernizacijskih procesa u promišljanju i proizvodnji arhitekture i gradogradnje zadanoga povijesnog segmenta predstavila „otvoreno društvo” Jacoba Jaapa Bakeme. Izložbom Open: A Bakema Celebration autora Guusa Beumera i Dirka van den Heuvela materijalizirala je Jaapovu viziju suvremene Nizozemske nakon Drugoga svjetskog rata, njezin novi nacionalni identitet za 20. stoljeće i životno okruženje zasnovano na uključivosti i poštivanju različitosti. Ta vizija fokus je i recentno objavljene knjige Jaap Bakema and the Open Society. Knjigu urednički potpisuje Van den Heuvel, profesor na Fakultetu arhitekture i izgrađenog okoliša Tehničkog sveučilišta u Delftu i voditelj Istraživačkog centra Jaap Bakema pri Institutu Het Nieuwe u Rotterdamu. Država blagostanja i progresivni arhitekti posvećeni njezinoj izgradnji okupljeni unutar skupine Team 10, respektabilne i utjecajne međunarodne grupe arhitekata čiji je Bakema bio spiritus movens, predmet su dugogodišnjeg Van den Heuvelova znanstvenog i kustoskog rada. Među njima je i danas već antologijsko djelo o skupini Team 10 (Team 10: In Search of a Utopia of the Present 1953-1981), koje potpisuje s Maxom Risseladom i Kennethom Framptonom.

$\rightarrow$ 


\section{Building}

a Welfare State

0

Dirk van den Heuvel, Jaap Bakema and the Open Society, Amsterdam: Archis, 20I8. IsBn 9789077966570

DOI: 10.31664/zu.2018.102.08

At the invitation of selector Rem Koolhas, and responding to the theme "Absorbing Modernity: I9I4-20I4" of the I4th Venice Architecture Biennale entitled Fundamentals, the Netherlands presented the "open society" by Jacob Jaap Bakema as a key moment of modernisation processes in the investigation and production of architecture and city building of a given historical segment. The exhibition Open: A Bakema Celebration, curated by Guus Beumer and Dirk van den Heuvel, materialised Jaap's vision of a modern Netherlands after the Second World War, its new national identity for the 2oth century and a living environment based on inclusivity and a respect for diversity. This vision was also the focus of a recently published book Jaap Bakema and the Open Society. The book was edited by Van den Heuvel, professor at the Faculty of Architecture and the Built Environment of the Delft University of Technology and the head of the Jaap Bakema Study Centre at the Het Nieuwe Instituut in Rotterdam. The welfare state and progressive architects dedicated to its establishment-gathered in Team Io, a respectable and influential international group of architects with Bakema as their spiritus movens - are the topic of Van den Heuvel's long scientific and curatorial work. Among his works is the now legendary book about Team io (Team Io: In Search of a Utopia of the Present 1953-I98I), which he edited together with Max Risselada and Kenneth Frampton.

$\rightarrow$ 


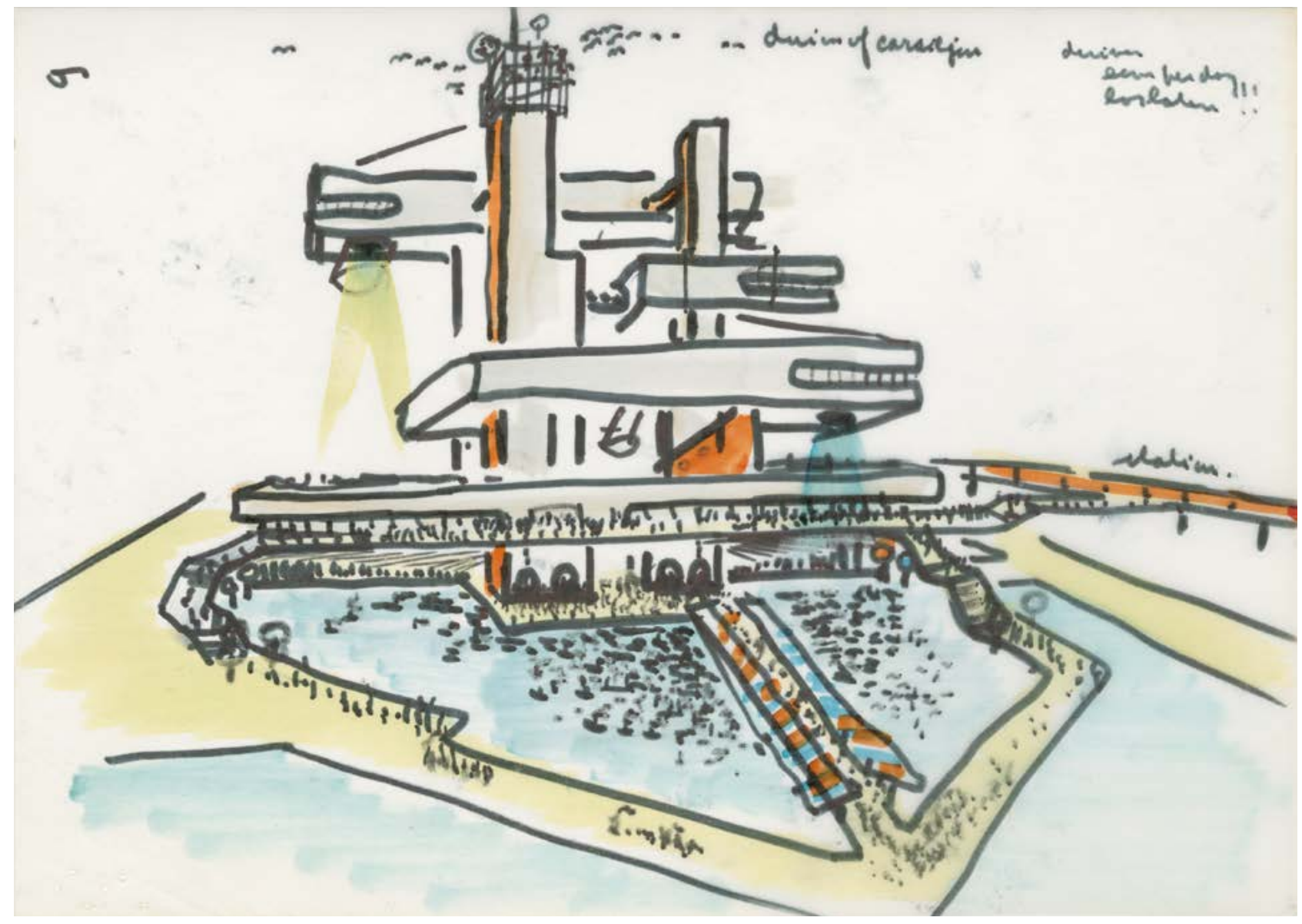




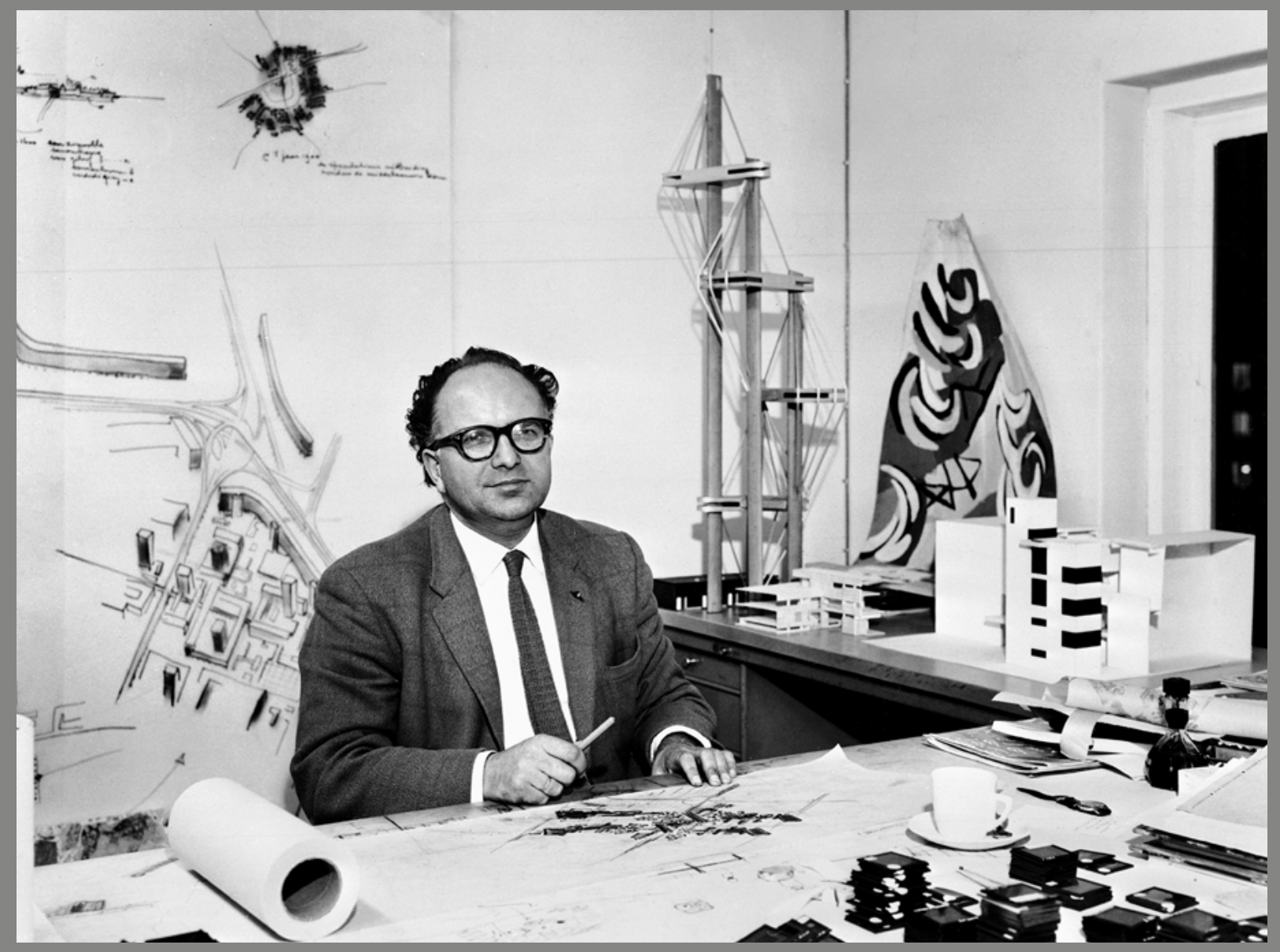


lako se promovira kao prva monografija o velikom arhitektu, knjiga Jaap Bakema and the Open Society daleko je od klasično strukturiranog prikaza autorova lika i djela. Dosljedno, od početka do kraja u sva tri poglavlja, knjiga ima dva ravnopravna aktera - „čovjeka s misijom” i „otvoreno društvo”, odnosno prati Bakemine teoretske zasade, koje se oživotvoruju u projektima i realizacijama kojima pak „gradi društvene odnose” i istražuje za njih ključne procese- „rast i promjene”. Nakon svakog od glavnih tekstova čiji su autori etablirani povjesničari arhitekture-M. Christine Boyer, Arnold Reijndorp i sam Van den Heuvel-slijedi koloplet bogato ilustriranih i sažeto elaboriranih projekata, od kojih su neki i tema zasebnih tekstova, pisane riječi samog Bakeme ili razgovori s njegovom kćeri Brittom Bakemom te arhitektima na koje je presudno utjecao i s kojima je suradivao, poput Hermana Hertzbergera i Carela Webera. Van den Heuvel odabrao je sedam ključnih Bakemnih tekstova nastalih između 1941. i 1971. godine, čime je knjiga postala i svojevrsni reader koji omogućava čitateljima neposredan dijalog s Bakemom u prvom licu. Među tekstovima su dakako najvažniji Towards an architecture of society i najpopularniji Relationship between men and things, kao i oni o pojedinim projektima, poput teksta o društvenom središtu Saint Louisa i teksta Post Box for the development of Habitat. Potonji je nastavak razgovora, koji je osobno inicirao Bakema, među novom poslijeratnom generacijom arhitekata, zainteresiranom za unaprjeđivanje arhitekture i prostornog planiranja, a još započetog na posljednjem okupljanju Međunarodnog kongresa moderne arhitekture (CIAM) u Otterlou 1959. godine.

Van den Heuvel je strukturirao bogato, gusto i slojevito štivo koje zahtijeva aktivnu participaciju čitatelja, što je neprijeporno bila svjesna namjera. Naime, Bakema isto očekuje od krajnjega korisnika, aktivnog člana demokratskog društva, ali i od arhitektonske struke. Bakema živi svoju viziju angažiranog arhitekta, graditelja novoga društva, djelujući u različitim poljima profesije. Spektar je širok-od voditelja biroa Van den Brook \& Bakema, tada jednog od najvećih ne samo u Nizozemskoj nego i u zapadnoj Europi, preko društvenog aktivista s vlastitom televizijskom emisijom u vrijeme kada je postojao samo jedan televizijski program, do profesora na Tehničkom sveučilištu u Delftu i gostujućeg profesora na brojnim inozemnim sveučilištima.

Bakema artikulira svoj vlastiti, autentičan izlaz iz kolotečine poslijeratnog modernizma-mehaničkog repetiranja koncepata funkcionalnog grada i masovne arhitektonske produkcije na tragu internacionalnog stila, čija je zadaća bila osigurati elementarni radni i stambeni prostor širokim narodnim masama. Oslanjajući se na vrijednosti predratne avangarde, koje upoznaje tijekom školovanja i prvih profesionalnih angažmana kod Marta Stama i Cornelisa van Eesterena, Bakema želi u znatno drugačijim društvenim i političkim prilikama ostvariti nešto višeuvažavajući različitosti samom arhitekturom oblikovati nove društvene odnose. Istomišljenike, članove skupine Team 10, pronalazi u okruženju CIAM-a čiji je aktivni član od 1947. pa do njegova raspuštanja, u čemu je imao istaknutu ulogu. Od 1953. godine pa sve do Bakemine smrti (1981.) sastanci Teama 10 bili su mjesto otvorene razmjene ideja i iskustava čiji je cilj humanizacija arhitekture i pronalaženje novih alata, koji će uz programska, metodološka i tehnološka rješenja voditi računa i o emocionalnim te psihološkim potrebama korisnika. Razmjena i propitivanje mišljenja moralna je obveza arhitekta koji stalno mora unaprjeđivati svoj rad posvećen boljitku društva. U produkciji prostora radni zadaci obuhvaćaju raspon „od stolice do grada”, što je bio i naziv Bakemine televizijske emisije; dapače, do čitave regije, što u konačnici vodi prema potpunoj integraciji arhitekture i prostornog planiranja. Knjiga Bakeminu viziju prvo donosi kroz urbanističke planove-stambenih naselja, gradskih središta i čitavih novih gradskih predjela-u kojima pratimo genezu osmišljavanja veće raznolikosti javnih prostora i stambenih tipologija pedesetih i šezdesetih godina. U drugome poglavlju nalaze se materijalizirani fragmenti tih planova, zajedno s javnim sadržajima-društvenim, kulturnim i trgovačkim centrima, sakralnim objektima, gradskim 
Although it is promoted as the first monograph on the great architect, the Jaap Bakema and the Open Society is far from a classically-structured presentation of an author's life and work. Consistently, from the beginning to the end of all three chapters, the book features two equal actors - "man with a mission" and "open society"-or rather, it follows Bakema's theoretical principles which are vivified by projects and realisations, through which he "builds social relations" and investigates key processes - "growth and change". Each of the main texts written by established historians of architecture-M. Christine Boyer, Arnold Reijndorp and Van den Heuvel himself-is followed by a tapestry of richly illustrated and succinctly elaborated projects, some of which are the topic of separate texts, Bakema's written words or conversation with his daughter Brita Bakema, and the architects he had a decisive influence on and with whom he cooperated, such as Herman Hertzberger and Carel Weber. Van den Heuvel chose seven of Bakema's key texts written between I94I and I97I, which makes the book into a sort of a reader that enables its readers to have a direct, one-on-one dialogue with Bakema. Among the texts, the most important is certainly "Towards an architecture of society" and the most popular "Relationship between men and things," as well as texts about particular projects like the one about the social centre of Saint Louis and the "Post Box for the development of the Habitat." The latter is a continued discussion that Bakema personally initiated among the new, postwar generation of architects, interested in advancing architecture and spatial planning, which was started at the last gathering of the International Congresses of Modern Architecture (CIAM) in Otterlo in 1959.

Van den Heuvel structured a rich, dense and layered reading that demands active participation from the reader, which was undoubtedly its intent. Namely, Bakema demanded the same from the end user, an active member of a democratic society, but also from the architectural profession. Bakema lived his vision of an engaged architect, builder of a new society, by being active in different fields of his profession; the spectrum is wide - from the head of the Van den Brook \& Bakema office, at that time one of the largest not just in the Netherlands but the entire Western Europe, through his role as a social activist with his own TV show at a time when there was only one TV channel, to a professor at the Delft University of Technology and a visiting professor at many foreign universities.

Bakema articulated his own, authentic way out of the rut of postwar modernism - a mechanic repetition of the concepts of a functional city and massive architectural production in the vein of the international style, whose task was to ensure rudimentary working and living space for the public at large. Leaning on the values of pre-war avant-garde, which he discovered during his schooling and first professional appointments with Mart Stam and Cornelis van Eesteren, Bakema wanted to achieve something more in significantly different social and political circumstances - by respecting differences, use architecture itself to shape new social relations. He found his allies (members of Team Io) in CIAM, whose active member he had been since I947 till its dissolution, in which he played a prominent role. From I953 until Bakema's death (I98I), the meetings of Team Io were characterised by an open exchange of ideas and experiences with the aim of humanising architecture and discovering new tools that would, in addition to programmatic, methodological and technological solutions, take into account the emotional and psychological needs of end user. Exchanging and challenging opinions is a moral obligation of architects who must constantly improve their work dedicated to the betterment of society. In the production of space, assignments ranged "from the chair to the city," which was the name of Bakema's TV show; and not just to the city but the whole region, which ultimately leads to a complete integration of architecture and spatial planning. This book presents Bakema's vision primarily through urban master plans - for housing estates, city centres and entire new city districts - through which we follow the genesis of designing greater diversity of public spaces and residential building typology of the I950s and I96os. 
Osim iscrpnoga prikaza

tri desetljeća nizozemske

arhitekture i izgradnje okoliša,

koji svojim značajem

prelaze nacionalne okvire,

knjiga u fokus stručne

i kulturne javnosti vraća

lik arhitekta, vizionara s misijom

koji predano radi na

izgradnji boljega materijalnog

okruženja, uvažavajući

pojedinca i propitujući svoj rad 
In addition to a comprehensive overview of three decades of Dutch architecture and built environment design, whose significance goes beyond the national borders, this book refocuses the attention of the expert and cultural public on the figure of the architect, a visionary with a mission who is dedicated to building a better material environment while respecting the individual and re-examining their own work 
vijećnicama i odmaralištima. Sve nabrojeno, bez iznimke, i u interijeru i eksterijeru sadrži umnožene i raznolike javne prostore koji nisu okvir za događanja, već njihov inicijator. Posljednji među odabranim projektima - paviljon Nizozemske na Svjetskoj izložbi u Osaki 1970._otvara temu Bakemina odnosa s njegovim prethodnicima, ali i novom generacijom nizozemskih arhitekata, koja će sedamdesetih preuzeti vodeće pozicije i u produkciji i u edukaciji, u prvom redu s Remom Koolhasom. S krizom socijalne države koncem šezdesetih, kao što to ističe Van den Heuvel, čitava generacija arhitekata skupine Team 10 našla se u procijepu između novih društvenih pokreta i birokracije socijalne države. Naime, iako prihvaćaju prve i kritiziraju drugu, aktivno sudjeluju u ostvarivanju njezinih ciljeva, što im se indirektno i predbacuje.

Istraživačima arhitekture u Hrvatskoj, ali i u široj regiji knjiga će biti dodatno privlačna kako zbog Bakemina referiranja na Split tako i zbog mnogostrukih izravnih poveznica s tim gradom. U Dioklecijanovoj palači Bakema je, naime vidio povijesni predložak, prototip strukture koja je opstala upravo zahvaljujući mogućnosti da se transformira i prilagođava. Na arhitektu je upravo zadatak da osigura taj osnovni infrastrukturni i konstruktivni okvir unutar kojega će korisnici, u skladu sa svojim potrebama, mijenjati unutarnji sadržaj. Nakon posjeta Splitu Bakema je u arhitektonskom časopisu Forum objavio članak „An Emperor's House at Split became a town for 3000 People" (1962.), koji je znatno utjecao na sve članove skupine Team 10. Ovdje treba napomenuti da je nizozemska arhitektura imala pak veliki utjecaj na arhitektonski diskurs u Hrvatskoj od sredine pedesetih nadalje. $U$ arhitektonskom ateljeu Johannesa van Broeka i Jakoba Bakeme, u sklopu programa tehničke pomoći Vlade Nizozemske Jugoslaviji, surađuju 1956. godine Radovan Nikšić i srpska arhitektica Milica Šterić, kasnije voditeljica projektnog odjela Energoprojekta. Nikšić neposredno po povratku iz Nizozemske, gdje je upoznaje i Geritta Rietvelda i J. J. P. Ouda, projektira jedno od najvažnijih arhitektonskih ostvarenja druge polovine 20. stoljeća ne samo u Hrvatskoj nego i u čitavoj Jugoslaviji-zgradu zagrebačkog Radničkog sveučilišta Moša Pijade (danas Pučko otvoreno učilište), projekt koji je Nikšić osobno predstavio i u Otterlou. Od te iste 1956. godine Bakemine se veze s Hrvatskom multipliciraju i dinamiziraju, a jadranska obala postala je njegovom čestom ljetnom destinacijom. Bakema je sudjelovao i na posljednjem Desetom kongresu CIAM-a u Dubrovniku 1956., rado ugošćavao zagrebačke studente arhitekture na studijskim putovanjima u Nizozemsku, da bi 1965. održao i dva predavanja na Arhitektonskom fakultetu Sveučilišta u Zagrebu.

Osim iscrpnoga prikaza tri desetljeća nizozemske arhitekture i izgradnje okoliša, koji svojim značajem prelaze nacionalne okvire, knjiga u fokus stručne i kulturne javnosti vraća lik arhitekta, vizionara s misijom koji predano radi na izgradnji boljega materijalnog okruženja, uvažavajući pojedinca i propitujući svoj rad. Svojim djelima i cjelokupnim djelovanjem, kao što je to istaknuo Herman Hertzberger, Bakema izražava ideološki, politički stav. Dakako, u sretnom trenutku europske povijesti iza sebe je imao podršku državnih i lokalnih vlasti. Usprkos tome, i u kontekstu promjena koje su zadesile arhitekturu u protekla četiri desetljeća, svodeći je na uslužnu djelatnost osuđenu na služenje krupnom kapitalu ili na puko preživljavanje, primjer Bakemina življenja i mišljenja arhitekture može biti inspirativan u traženju mogućih odgovora na današnji društveni trenutak - zbog njegova sustava etičkih vrijednosti, bezrezervne predanosti i inzistiranja na javnom interesu te uključivanja svih dionika društva u proces izgradnje životnog okoliša. 
The second chapter features materialised fragments of these plans, together with public institutions and amenities - social, cultural and commercial centres, religions buildings, city halls and resting places. All of the above, without exception, contain in their interior and exterior multiplied and diverse public spaces which are not a framework for events but their initiator. The last of the chosen projects - the Dutch pavilion for the world's fair Osaka Expo in I970-opened up the topic of Bakema's relationship with his predecessors, but also with the generation of Dutch architects who would take up leading positions in both production and education in the I970s, primarily Rem Koolhas. As Van den Heuvel pointed out, with the crisis of the social state at the end of I960s, a whole generation of Team Io architects found themselves in a gulf between new social movements and the bureaucracy of the social state. Namely, even though they accepted the former and criticised the latter, the blame for taking an active part in achieving the state's goals is indirectly laid at their feet.

To architecture researchers in Croatia but also the wider region, this book will be even more attractive because of Bakema's referencing of Split as well as his many direct connections with that city. Namely, in the Diocletian's Palace, Bakema saw a historical paradigm, a prototype of a structure that survived precisely because of its ability to transform and adapt. The task of the architect is to ensure this fundamental infrastructural and constructive framework within which its users will be able to change the inner content in accordance with their needs. After visiting Split, Bakema published an article in the architectural journal Forum entitled "An Emperor's House at Split became a town for 3000 People" (I962), which had a significant impact on all members of Team Io. Here it should be noted that Dutch architecture greatly influenced architectural discourse in Croatia from mid I950s onwards. As part of a Dutch government's technical assistance programme to Yugoslavia, the architectural office of Johannes van Broek and Jakob Bakema in 1956 hosted Radovan Nikšić and Serbian architect Milica Šterić, who later became the head of Energoprojekt's design department. Soon after returning from the Netherlands, where he also met Gerrit Rietveld and J. J. P. Oud, Nikšić designed one of the most important architectural achievements of the second half of the 2oth century, not just in Croatia but in whole Yugoslavia - the building of the Moša Pijade Worker's University in Zagreb (today Public Open University), a project which Nikšić personally presented in Otterlo. Starting from that same year, Bakema's ties with Croatia multiplied and became more dynamic, while the Adriatic coast became his frequent summer destination. Moreover, Bakema took part in the last, Ioth CIAM Congress in Dubrovnik in I956, he gladly hosted architecture students from Zagreb on their study visits to the Netherlands, and in I965 gave two lectures at the Faculty of Architecture in Zagreb.

In addition to a comprehensive overview of three decades of Dutch architecture and built environment design, whose significance goes beyond the national borders, this book refocuses the attention of the expert and cultural public on the figure of the architect, a visionary with a mission who is dedicated to building a better material environment while respecting the individual and re-examining their own work. As Herman Hertzberger pointed out, in his projects and work in general Bakema expressed an ideological, political stance. Of course, in that happy time of European history, he had the support of state and local governments. Still, even in the context of changes that affected architecture in the last four decades and reduced it to a service industry condemned to serve the big business or barely survive, the example of Bakema's living and thinking of architecture can inspire a search for possible answers to today's social moment - thanks to his ethical value system, unconditioned dedication and insistence on public interest, as well as the inclusion of all social stakeholders in the process of building a living environment. 


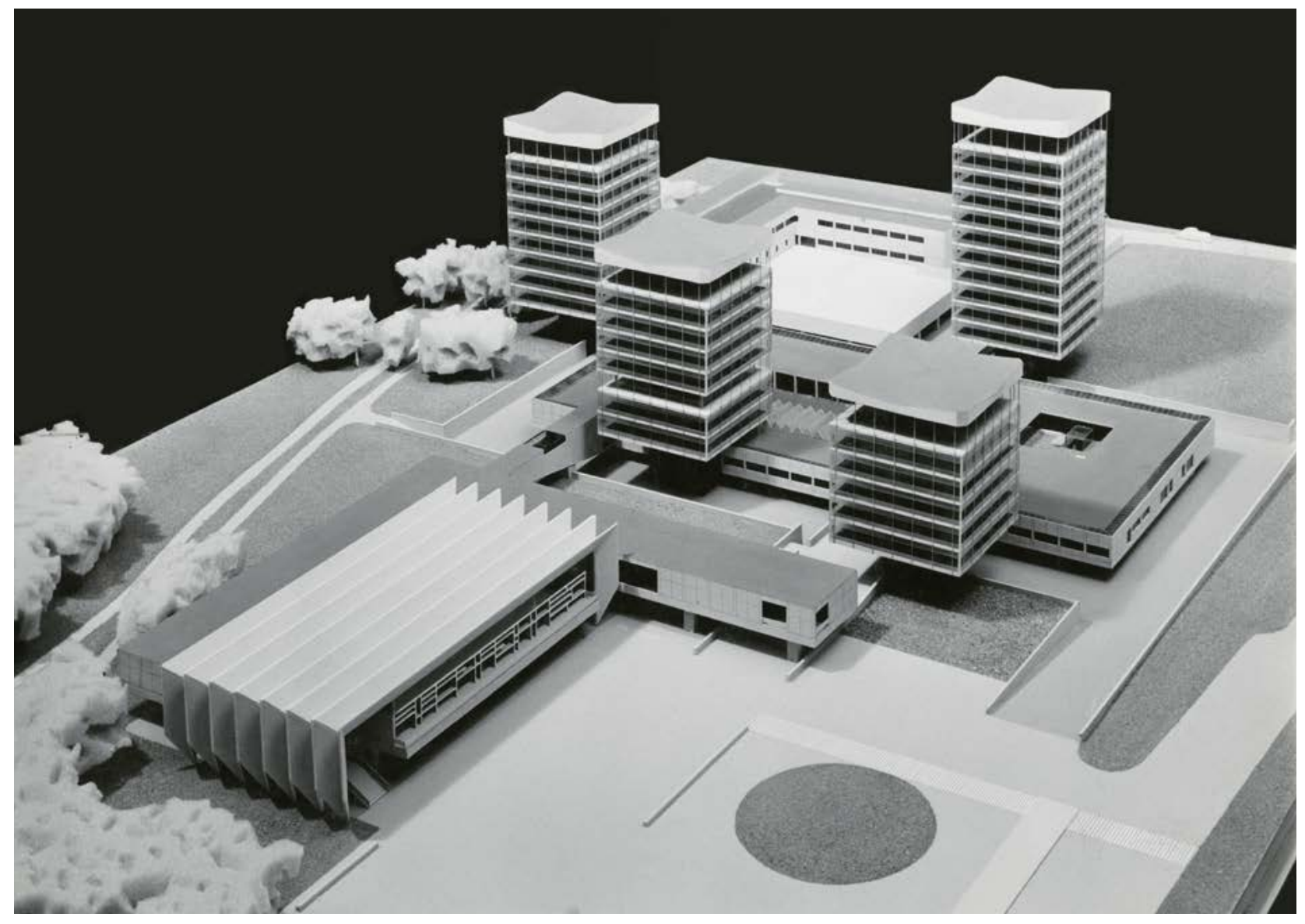

$\uparrow$

Maketa gradske vjećnice u Marlu (1957.-67.) [zbirka Het Nieuwe Instituut, BAKE_ph22]

Model of the town hall in Marl (I957-67) [collection Het Nieuwe Instituut, BAKE_ph22]

Djeca ispred crkve u Nageleu (1960.) koju je projektirao Jaap Bakema [zbirka Borekbakema] / Children in front of the church Jaap Bakema designed in Nagele (I960) [collection Broekbakema] 


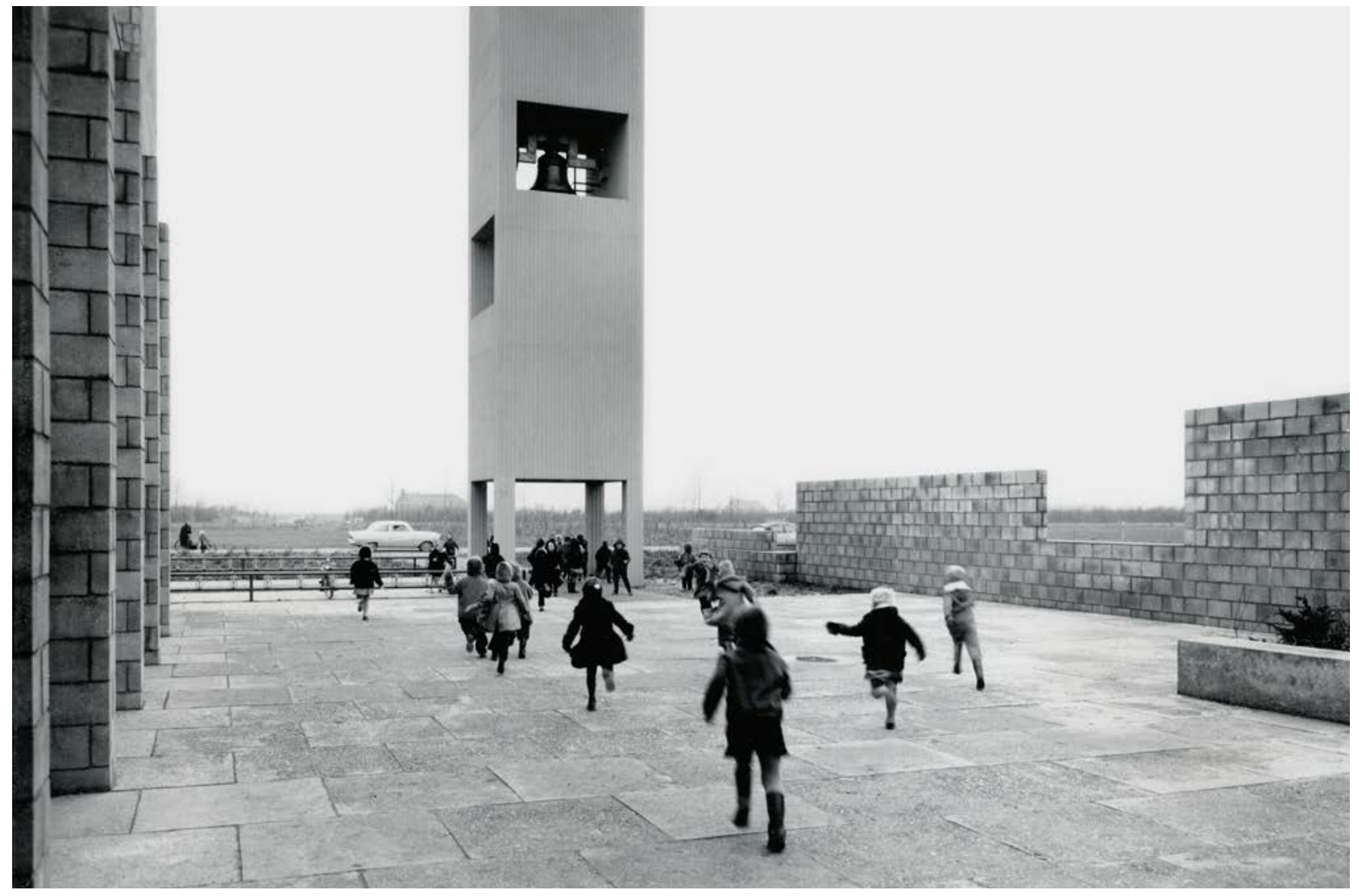

